\title{
MORPHOLOGICAL AND SOIL DETERMINANTS OF FOREST COVER CHANGES IN ŚWIĘTOKRZYSKI NATIONAL PARK AND ITS BUFFER ZONE IN THE LAST 200 YEARS
}

\author{
Tadeusz Ciupa, Roman Suligowski, Grzegorz Watek \\ Institute of Geography, Jan Kochanowski University in Kielce, Poland
}

Manuscript received: 14 May 2014

Revised version: 31 December 2014

\begin{abstract}
Ciupa T., SuligowSKi R., WAŁeK G.., 2015. Morphological and soil determinants of forest cover changes in Świętokrzyski National Park and its buffer zone in the last 200 years. Quaestiones Geographicae 34(1), Bogucki Wydawnictwo Naukowe, Poznań, pp. 55-63, 1 table, 5 figs. DOI 10.1515/quageo-2015-0005, ISSN 0137-477X.

ABSTRACT: The research described in the paper utilized GIS methods and comparative cartography in order to analyze changes in forest cover in the period 1800-2011 in the Świętokrzyski National Park $\left(76.26 \mathrm{~km}^{2}\right)$ and its buffer zone $\left(207.86 \mathrm{~km}^{2}\right)$. The research was done for predefined elevation intervals, slope gradients, and genetic soil types. Source materials included historical maps as well as a digital elevation model. Changes in forest cover were noted in spatial and temporal terms and were usually linked to morphology and soil type. While the 19th century was characterized by intense deforestation, this process reversed starting in the early 20th century. Nevertheless, forest cover in the study area has still not returned to its state from 1800.
\end{abstract}

KEY WORDS: forest, elevation, slope gradient, soils, Świętokrzyski National Park

Address of the corresponding author: Tadeusz Ciupa, Institute of Geography, Jan Kochanowski University in Kielce, Kielce, Poland,e-mail: tciupa@ujk.edu.pl

\section{Introduction}

Forest cover change is a global problem, and was tackled in many papers. In Europe these studies were undertaken i.a. in Germany (Wulf et al. 2010), Italy (Di Fazio et al. 2011, Puddu et al. 2012), and the Czech Republic (Skalos et al. 2012). The mentioned authors indicated that changes in forest cover are an effect of a number of environmental, sociological, and economic conditions. The contemporary Polish research literature also includes many papers describing the analysis of forest cover changes at various spatial and temporal scales (Więcko 1986, Ciołkosz, Poławski 2005, Markuszewska 2005, Polna 2005, Giętkowski 2009, Kozak 2010, Gielarek et al. 2011, Kunz 2012, Macias, Szymczak 2012). The cited papers are based largely on cartographic materials which have become a key feature of scientific papers on this topic starting from the period 1918-1939. Szymański (1979) presents a wide variety of cartographic sources and papers for Poland.

Forests in the Świętokrzyskie Mountains in central Poland have been studied by many researchers since the $19^{\text {th }}$ century (Barański 1972). A review of the research literature on spatial forest research from the last 200 years reveals three main areas of interest: (1) Degree of economic use of forests found in the region, including those in the Świętokrzyski National Park (Połujański 1854, Aleksandrowicz 1880, Szafarkiewicz 1885, Błaszczyk 1959, Kasprzyk 1961, Krysztofik 1976, Krysztofik, Zieliński 1976, Plan ochrony... 2000), (2) Changes in the extent of forest cover driven by 
historical, economic, and political determinants (Romanowska 1934, Więcko 1948, Zaręba 1958, Szymański 1978, 1983, 1993, Malczyk, Świeżak 2008, Siuta, Żukowski 2011), (3) Morphological and soil determinants of the forest cover in a given region. The third area of interest is, however, relatively poorly covered by the research literature of the region (Reniger 1956, Kowalkowski 2000).

Hence, the Świętokrzyskie Mountains, including the Świętokrzyski National Park (ŚNP), are the only mountain range in Poland without the forest cover having been analysed in the context of environmental determinants including relief and soil cover.

The purpose of this paper is then to analyze the changes in the forest cover over the last 200 years in the area within contemporary borders of the Świętokrzyski National Park and its buffer zone. The analysis includes factors such as elevation, slope gradient, and genetic soil type.

The development of new GIS technologies in recent years and an increasing access to archived cartographic materials have made it possible to detect and track changes in the forest cover for selected periods of time (Terefenko, Furmańczyk 2005, Kozak et al. 2007a, b, 2008, Wulf et al. 2010, Skalos et al. 2012). Newly available digital elevation models (DEM) help to analyze changes in the forest cover by including elements such as local morphology. DEM analyses concerning forest cover research were conducted in Europe by Hörsch (2003) for the Swiss Alps and by Geri et al. (2010) for Tuscany. In Poland, Kozak et al. (2007b) carried out a DEM analysis for the Carpathian Mountains, while Szymura et al. (2010) did it for the Sudety Mountains. These studies demonstrate the significant meaning of morphological determinants such as elevation, slope gradient and aspect for forest cover changes in mountain areas.

\section{Study area}

The Świętokrzyski National Park $\left(76.26 \mathrm{~km}^{2}\right)$ and its buffer zone $\left(207.86 \mathrm{~km}^{2}\right)$ are located in the central part of the Świętokrzyskie Mountains (Fig. 1). The concept of a national park in this region emerged in the early $20^{\text {th }}$ century and was finally realized in 1950. It was the first national park to be established in Poland after World War II (Čmak 2000).

The area is characterized by virtually parallel lines of ridges generally following a WNW-ESE geometry, associated with regional lithology and tectonics. Expansive valleys characterized by flat floors and small height differences can be found between the lines of hills (Kowalski 2000). Elevation in the Park and its buffer zone varies from 210 to 612 meters above sea level, while local slope gradients reach $20^{\circ}$. The Park features its own distinct climate relative to neighboring areas (Kłysik 1974). Precipitation totals are higher at summit elevations by an average of $200 \mathrm{~mm}$ per year and the air temperature is lower by an average of $1.5^{\circ} \mathrm{C}$ relative to adjacent valleys (Olszewski et al. 2000).

The soils in the study area are characterized by a mosaic pattern determined by a variety of environmental factors, while their relationship with forest type has already been shown by Kowalkowski (2000). Summit areas in the Park are dominated by skeletal mountain soils, while lower elevations and the Park's buffer zone are characterized by soils formed on loess, clay and alluvial dust deposits. Valleys in the study area feature marshy soils and alluvial soils.

\section{Research materials and methods}

Source materials included high resolution scans of maps produced over the course of two centuries: (1) Map of Western Galicia by Colonel Mayer von Heldensfeld - scale: 1:28 800 (five sheets issued in the period 1801-1804), (2) Map of Western Russia - scale: 1:100 000 (two sheets issued in 1914 and 1915), (3) Tactical Map of Poland produced by the Military Geographic Institute - scale: 1:100 000 (two sheets issued in 1931 and 1934), (4) General Staff Map produced by the Polish Army - scale: 1:50 000 (four sheets issued in the period 1985-1988), (5) Environmental Map - scale: 1:50 000 (four sheets issued in 2011). Old maps were published on the basis of field mapping which could have been performed years before map's publication. Regarding the timeliness of the data presented on the abovementioned maps, the following years were used in the analyses: Map of Western Galicia - 1800, Map of Western Russia - 1900, Tactical Map of 


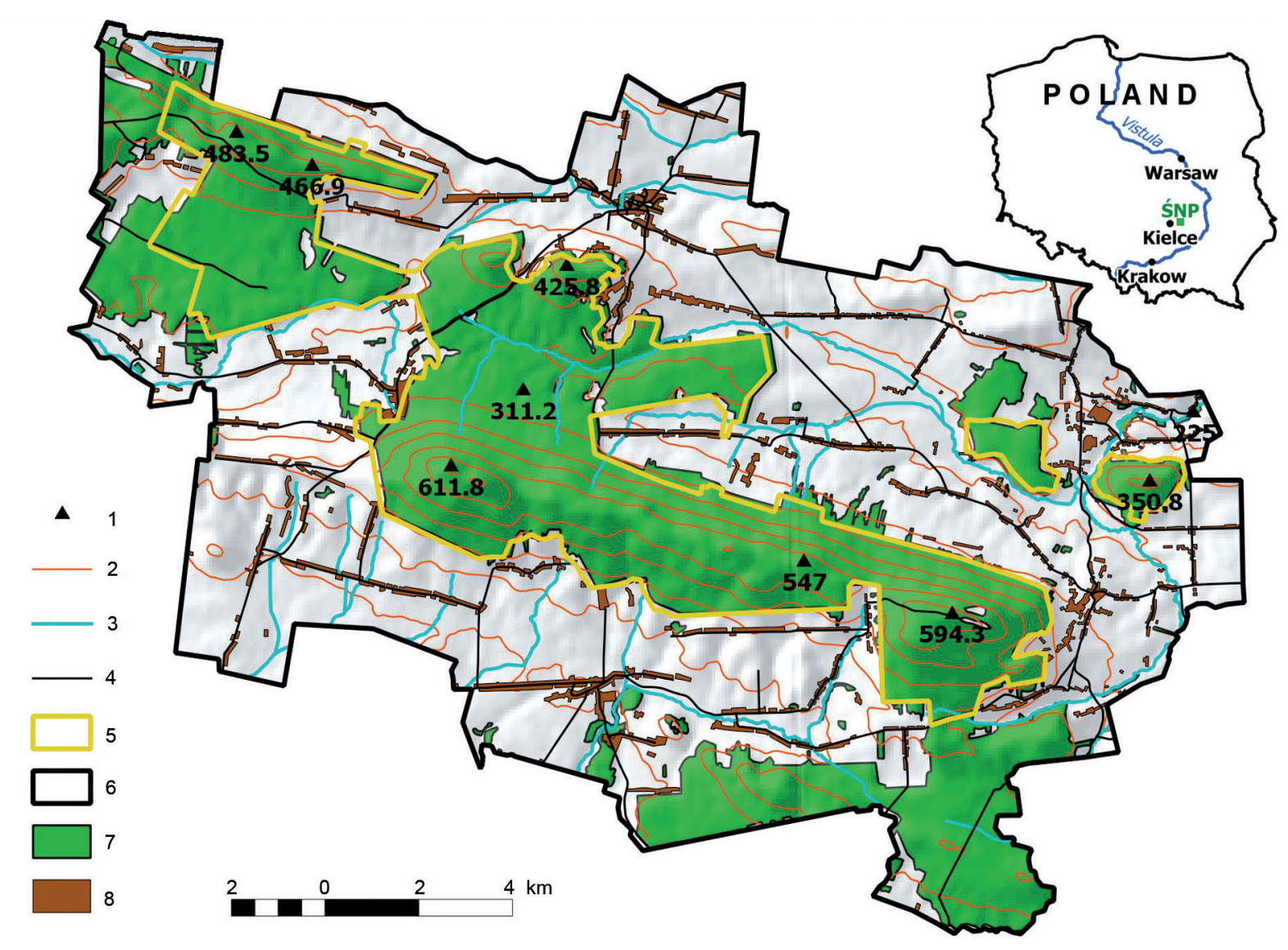

Fig. 1. Location of the Świętokrzyski National Park and its buffer zone

1 - summits, 2 - contour lines, 3 - rivers, 4 - roads, 5 - park boundary, 6 - boundary of the buffer zone, 7 - forests as of 2011, 8 - built-up areas

Poland - 1930, General Staff Map - 1983, Environmental Map - 2011. Timeliness of the two oldest maps has been estimated according to the literature (Słomczyński 1934). In the case of the three other maps it is directly marked on the sheets, therefore the timeliness of the oldest map in the series was taken into account. Those years make frames of the time periods used in the forest cover change analysis: 1800-1900, 1900-1930, 1930-1983, 1983-2011. A Soil Map of Poland from 1961 in the scale of 1:300 000 was used to determine the spatial dimensions of genetic soil types (Musierowicz 1961). Morphometric analysis was performed with the use of the SRTM3 digital elevation model (Shuttle... 2004).

The analysis was performed using Quantum GIS 1.8.0 and SAGA GIS 2.0.2 software. The first part of data was prepared with Quantum GIS in which scanned topographical maps were georeferenced to the European Terrestrial Reference System (ETRS) 1989/Poland CS92. Then forest areas were digitalized by on-screen vectorization method to the shapefile format, starting from the latest to the oldest map, according to the comparative cartography methods of retrogression and elimination (Stevens, Tree 1951, Jankowska, Lisiewicz 1998, Wilson 2005). After these operations, the forest areas were calculated in the attribute table. Similar data preparation methodology was used to prepare digital data from the soil map. SAGA GIS software was used to analyze SRTM3 digital elevation model and delineate elevation and slope gradient classes. Finally, map overlay methods (difference and intersect) were used to analyze forest cover changes between the analyzed time intervals in elevation, slope gradient and genetic soil type classes. For every soil group, the mean annual index of forest cover change (ha.year ${ }^{-1}$ ) for each studied time period has been calculated with the use of a spreadsheet.

\section{Results}

Changes in the forest cover were studied separately for the Świętokrzyski National Park and 
its buffer zone with respect to the morphology and soil cover.

Cartographic materials indicate that the forest cover in the study area was the greatest at the beginning of the study period - in the year 1800 - and amounted at $134.0 \mathrm{~km}^{2}$, which constituted $47.2 \%$ of the study area (Table 1, Fig. 2A).

The forest cover in the study area decreased to $94.8 \mathrm{~km}^{2}$ by the year 1900 (Fig. 2B). In the Świętokrzyski National Park, the forest cover decreased from $70.0 \mathrm{~km}^{2}$ in 1800 to $65.3 \mathrm{~km}^{2}$ in 1900 , while in its buffer zone, the forest cover decreased from $64.0 \mathrm{~km}^{2}$ to $29.5 \mathrm{~km}^{2}$ during the same time period. Hence, $13.8 \%$ of the entire study area was affected by deforestation, with deforestation of $6.2 \%$ in the National Park and $16.6 \%$ in the Park's buffer zone (Table 1). The mean annual rate of deforestation in the period 1800-1900 was $39.2 \mathrm{ha} \cdot \mathrm{yr}^{-1}$. In the Park itself, the rate of deforestation was 4.7 ha. $\mathrm{yr}^{-1}$.

The forest cover has been increasing steadily since 1900 in the area of the Świętokrzyski National Park, but not in its buffer zone, where deforestation continued until 1930. In 1983 the forest cover in the study area increased to $100.8 \mathrm{~km}^{2}$ $(35.5 \%)$ and the rate of growth was $7.9 \mathrm{ha} \cdot \mathrm{yr}^{-1}$. The annual rate of growth after 1983 increased to $19.6 \mathrm{ha} \cdot \mathrm{yr}^{-1}$ across the entire study area. By 2011, forests accounted for $37.4 \%\left(106.3 \mathrm{~km}^{2}\right)$ of the study area (Fig. 2C). The forest cover increased by $11.5 \mathrm{~km}^{2}$ in comparison to 1900 , with $6.3 \mathrm{~km}^{2}$ of a new forest in the National Park itself. As a result of that, the contemporary forest cover area in the ŚNP is larger than in 1800. Nevertheless, the forest cover in the entire study area (the ŚNP and the buffer zone) has still not returned to its state as from 1800.

A digital elevation model was used to analyze the influence of geomorphological factors on the forest cover changes across the study area. The model was used to identify six distinct elevation categories (expressed in meters above sea level): 210-250, 250-300, 300-350, 350-400, 400-500, 500-612, which extent results from the elevation histogram natural breaks analysis. This also allowed for a better comparison of the classes areas.

The research has shown that the largest deforestation in the $19^{\text {th }}$ century occurred at the elevations between 400 and 500 meters above sea level - a decrease of $5.4 \mathrm{~km}^{2}(16.3 \%)$. Two lower elevation intervals were also characterized by deforestation of more than 15\%: 350-400 meter interval and 300-350 meter interval. Both elevation zones featured large woodland areas suitable for agriculture and settlement. Finally, summit areas found at 500 meters above sea level or more experienced the lowest deforestation (Fig. 3).

Areas, already highly deforested in 1800 (forest cover: $14.2 \%$ ), found at elevations of less than 250 meters continued to undergo deforestation until 1930. The forest cover decreased here to $1.2 \%$ by 1930. A similar pattern of deforestation was noted for the 250-300 meter elevation interval (Fig. 3). Research showed that the forest cover began to increase in virtually every elevation interval starting from the early $20^{\text {th }}$ century. In 1930 the largest rate of increase was noted for the 400-500 meter elevation

Table 1. Forest data for the Świętokrzyski National Park (ŚNP) and its buffer zone (BZ) for the period 1800-2011

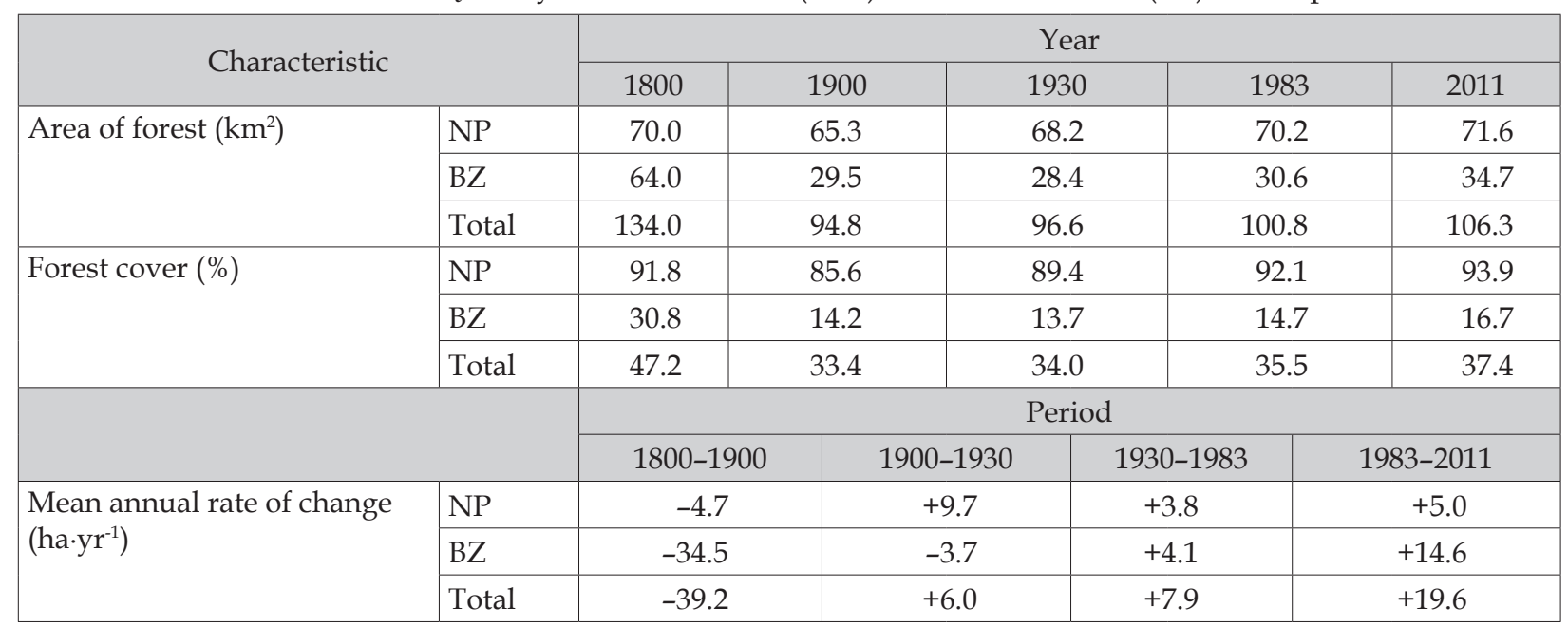



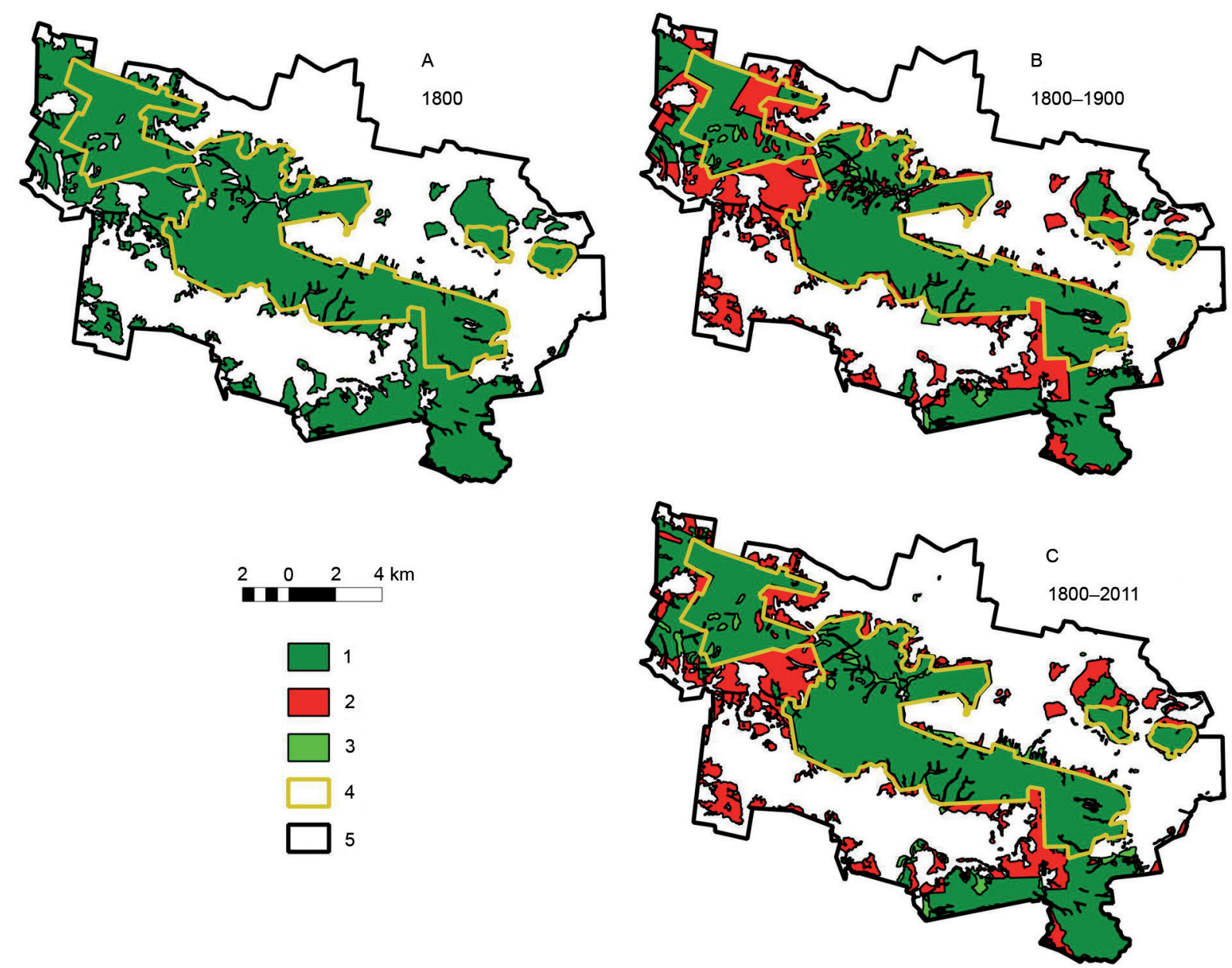

Fig. 2. Forest cover in the Świętokrzyski National Park and its buffer zone in 1800 (A) and subsequent changes in the periods 1800-1900 (B) and 1900-2011 (C)

1 - forests, 2 - deforestation, 3 - reforestation, 4 - park boundary, 5 - buffer zone boundary

interval. This particular interval is of negligible agricultural importance. Finally, the period 1983-2011 was characterized by significant economic changes in Poland and in other parts of Central and Eastern Europe. The highest rate of new forest growth in the study area during this time was noted for the three lowest elevation intervals considered in this paper. Some of the reasons for this included intentional reforestation and natural succession across unused agricultural lands.

Changes in the forest cover in the Świętokrzyski National Park and its buffer zone were also analyzed in relation to slope gradient. Five slope gradient categories were identified: 0-3, 3-6, $6-10,10-15,>15^{\circ}$ according to the mechanism of surface water erosion processes in Poland (Józefaciuk, Józefaciuk 1996). All analyzed slope gradient categories were characterized by deforestation in the $19^{\text {th }}$ century (Fig. 4). However, the largest rates of deforestation were noted for the

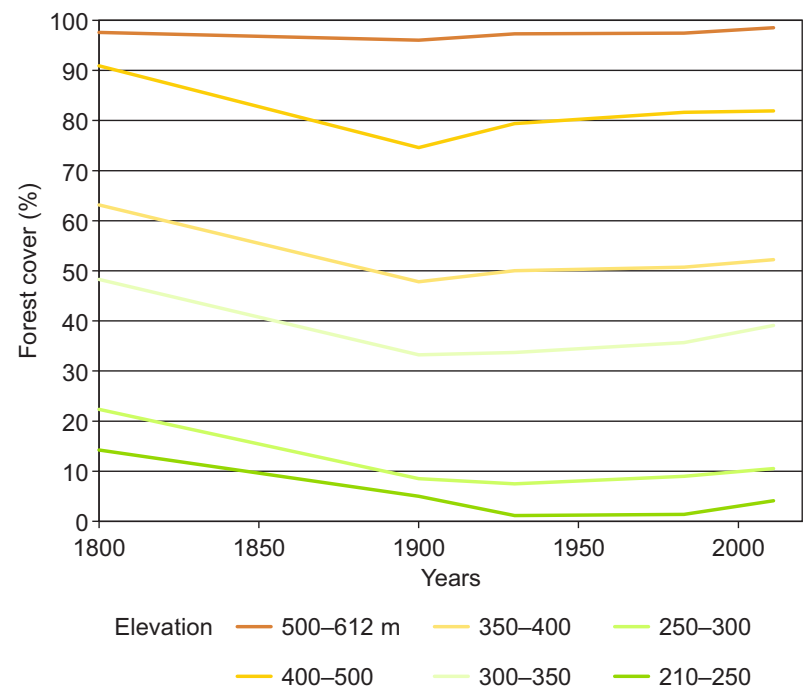

Fig. 3. Changes in the forest cover for selected elevation intervals in the Świętokrzyski National Park and its buffer zone since the year 1800 


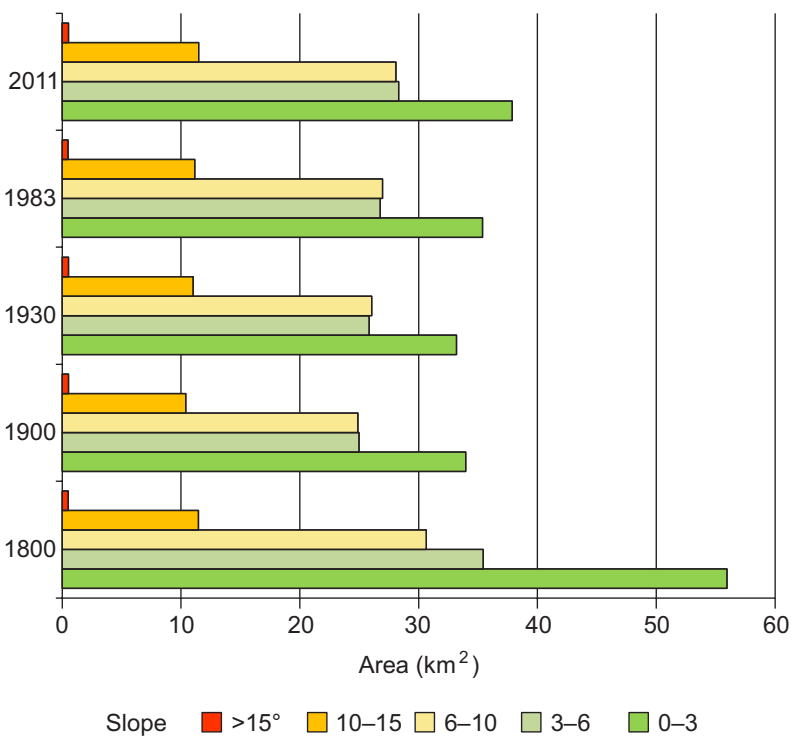

Fig. 4. Changes in the forest cover for selected slope gradient intervals in the Świętokrzyski National Park and its buffer zone since the year 1800

areas with the smallest slope gradients $\left(0-3^{\circ}\right)$. This category includes $39.3 \%$ of the study area and is characterized by the best conditions for agriculture and the lowest susceptibility to surface water erosion. Increases in forest cover have been noted for virtually every gradient category since the early $20^{\text {th }}$ century. In one exceptional case, reforestation began to increase in the $0-3^{\circ}$ category in 1930 (Fig. 4).
The Soil Map of Poland was used to create the following soil categories for the study area: (1) sand-based $-5.7 \%$ of the study area, (2) clay $19.2 \%$, (3) loess $-54.5 \%$, (4) alluvial dust deposits - 9.1\%, (5) marshy and alluvial soils - 0.7\%, (6) rocky and skeletal soils on non-carbonate rocks $10.8 \%$. The forest cover (area and percentage) was calculated for each analyzed soil type and for each studied time period, and used to identify change patterns in the Świętokrzyski National Park and its buffer zone. Mean annual changes in the forest cover were also calculated for each studied time interval. Figure 5 shows the results for the periods 1800-1900 as well as for 1930-2011. The mean annual index of forest cover change calculated herein was negative for the period 1800-1900, which indicates deforestation across all soil types. Deforestation was greatest in the case of loess-type and clay-type soils - about $14 \mathrm{ha} \cdot \mathrm{yr}^{-1}$. The highest deforestation rate in the $19^{\text {th }}$ century was noted for the areas characterized by the best soil conditions for agriculture in a time of rising demand for farmland. Deforestation continued to occur across loess-type and sand-type soils in the study area until the early $20^{\text {th }}$ century, while areas characterized by other soil types had already entered the reforestation stage at the time.

On the other hand, the forest cover increased between 1930 and 2011 for every soil type (Fig.

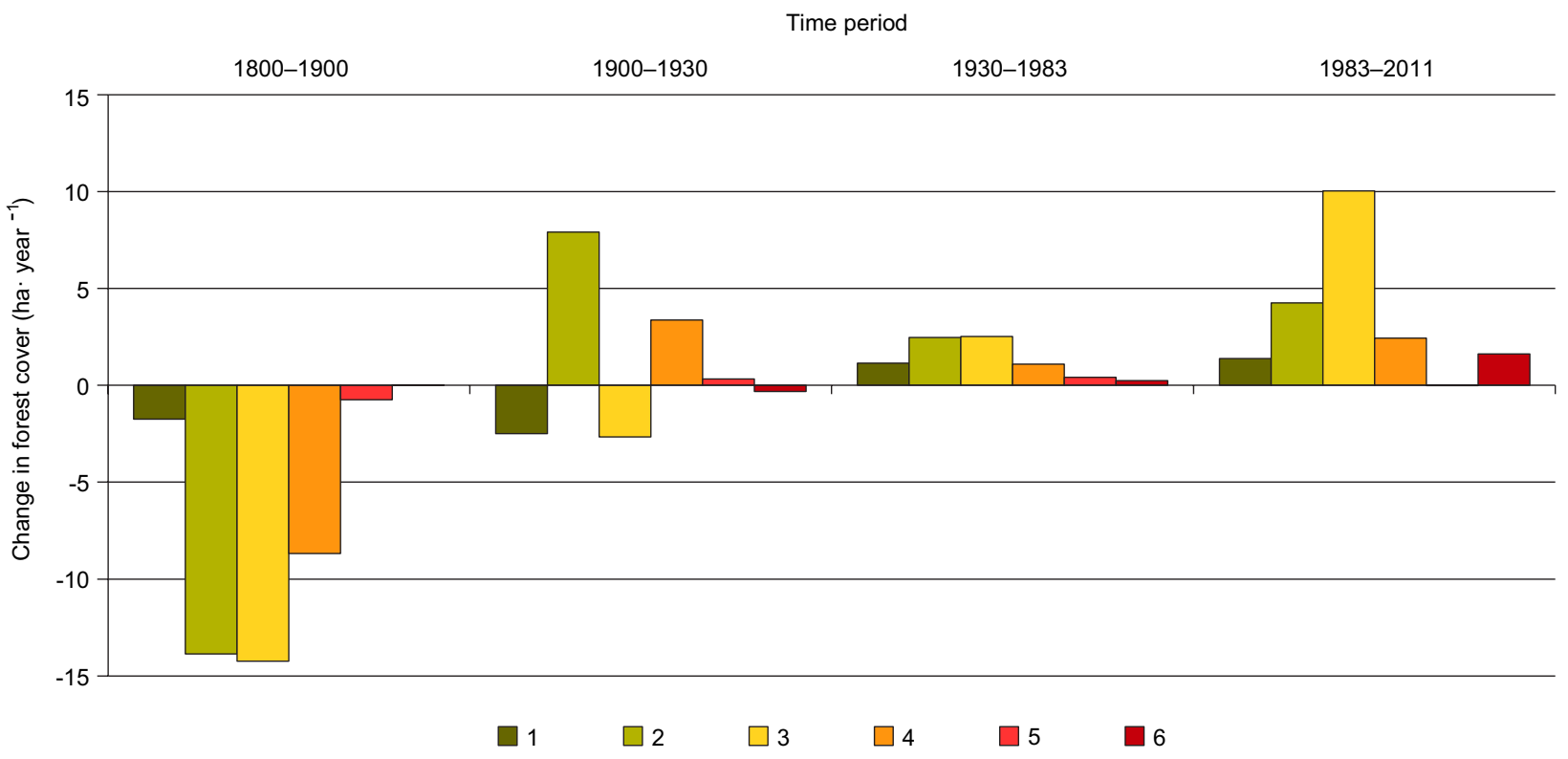

Fig. 5. Changes in the forest cover for selected soil types found in the Świętokrzyski National Park and its buffer zone since the year 1800

Soil types: 1 - sand-based, 2 - clay-based, 3 - loess-based, 4 - alluvial dust deposits, 5 - marshy and alluvial soils, 6 - rocky and skeletal soils. 
5). Today, increases in the forest cover are particularly visible in the case of loess-type soils (approx. $\left.10 \mathrm{ha} \cdot \mathrm{yr}^{-1}\right)$.

\section{Discussion and conclusions}

The paper attempts to show the significance of morphological and soil-based factors in the forest cover changes in the Świętokrzyski National Park and its buffer zone during the last 200 years.

The rate of deforestation in the National Park was quite low in the $19^{\text {th }}$ century compared with that in the Park's buffer zone. In the Świętokrzyski National Park the process of deforestation was documented from 1800 to 1900 , whereas in the buffer zone it lasted until the 1930. After the turning points in the mentioned years, afforestation began and it continues until present. Despite ongoing afforestation, the forest cover in the analyzed area has not returned to its state from the year 1800. A similar deforestation-afforestation trend was observed throughout Northern Europe until the mid-19 $9^{\text {th }}$ century. In Southern Europe, deforestation continued until the 1970s (Rudel et al. 2005).

Regarding the forest cover changes in elevation and slope categories, deforestation was observed everywhere, from the most to the least accessible parts of land, reaching high elevations and steep slopes in the National Park in 1900 and in the Park's buffer zone in 1930. After 1900 and 1930 continuous afforestation could be noted, covering at first the least accessible areas (ongoing to the 2011), while the areas of good agricultural suitability (in morphological context) kept being covered with the forest. This process is reinforced by additional nature preservation measures introduced in the area: since the mid$20^{\text {th }}$ century - the Świętokrzyski National Park and - since the beginning of the $21^{\text {st }}$ century PLH260002 Łysogóry are a part of the pan-European Natura 2000 system. Deforestation and following afforestation have been observed for all elevation and slope gradient intervals.

Forest cover changes analysis, in addition to genetic soil types, showed a tendency similar to the one of the morphological determinants. At first, deforestation occurred on the soils best for agricultural purposes, then it covered less fertile and usable areas. After 1900 and 1930 affores- tation did not follow such a clear pattern but it also seemed to be connected with soils fertility. Surprisingly, in the periods 1930-1983 and 19832011 the highest afforestation concerned loess soils. Those areas were used intensively for agricultural purposes for more than a century. For this reason, the soils in the ŚNP buffer zone became less fertile over the years and consequently less profitable for farmers who have largely abandoned the buffer zone in the recent years.

In the $19^{\text {th }}$ century, environmental conditions were the most important for agricultural production led by local populations. However, in the $20^{\text {th }}$ century, the key issues were economics and politics instead of local soil type and relief. This could partly explain afforestation on fertile soils. Broad description of such patterns can be found in a number of papers analyzing forest cover and its relationship with elevation, natural succession and human impact in Europe (Didier 2001, Hörsch 2003, Kozak 2005, Kozak et al. 2007b, Geri et al. 2010). Also the relationship between the forest cover and soil types in mountain areas, and indirectly with the agricultural potential, was studied by MacDonald et al. (2000) and Wulf et al. (2010). Szymura et al. (2010) analyzed the impact of relief and non-environmental factors on the forest cover in the $19^{\text {th }}$ and $20^{\text {th }}$ centuries in the context of pan-European trends, showing strong relationship between the forest cover and two variables: elevation and slope gradient.

The economic and political situation in Poland in the period 1800-1930 resulted in a significant decline in forest cover. Some of the reasons for deforestation included shortage of farmland in rural areas, lack of appropriate legislation, lack of local government oversight, and increasing industrialization in the region (Szymański 1978, 1983, 1993). In addition, small forests found near villages served as sources of firewood for home heating purposes. On the other hand, the $20^{\text {th }}$ century was characterized by afforestation due to widespread abandonment of overused farmland, migration of rural residents to cities, as well as the introduction of environmental protection laws (Szymański 1993). Natural succession in the last several decades was documented earlier in other temperate forests throughout Europe (Piussi 2000, Kozak et al. 2007b, Baumann et al. 2012, Bose et al. 2014). 


\section{References}

Aleksandrowicz B., 1880. Obecny stan lasów i sadów owocowych w Królestwie Polski (The present state of forests and orchards in the Kingdom of Poland). Ekonomista 41-46.

Barański S., 1972. Lasy Gór Świętokrzyskich w "Sylwanie" z lat 1820-1858 (Forests of Świętokrzyskie in Sylwan from 1820 to 1858). Sylwan 66(3): 55-60.

Baumann M., Ozdogan, M., Kuemmerle, T., Wendland K.J., Esipova E., Radeloff, V.C., 2012. Using the Landsat record to detect forest-cover changes during and after the collapse of the Soviet Union in the temperate zone of European Russia. Remote Sensing of Environment 124: 174-184.

Błaszczyk H., 1959. Organizacja techniczno-gospodarcza lasów górniczych województwa kieleckiego w latach 1816-1869 (The techno-economic structure of mining forests in Kielce Voivodeship from 1816 to 1869). Rocznik WSR Poznań 7.

Bose A.K., Schelhaas M-J., Mazerolle M.J., Bongers F., 2014. Temperate forest development during secondary succession: effects of soil, dominant species and management. European Journal of Forest Research 133(3): 511-523.

Ciołkosz A., Poławski Z., 2005. Zmiany użytkowania ziemi w Polsce w II połowie XX w. na podstawie analizy danych kartograficznych (Land use changes in Poland in the second half of 20th century based on the analysis of land use maps). Roczniki Geomatyki 3(2): 17-26.

Čmak J., 2000. Historia utworzenia Świętokrzyskiego Par$\mathrm{ku}$ Narodowego (The history of establishing of the Świętokrzyski National Park). In: Cieśliński S., Kowalkowski A. (eds) Monografia Świętokrzyskiego Parku Narodowego. Wyd. ŚPN, Bodzentyn-Kraków: 31-41.

Di Fazio S., Modica G., Zoccali P., 2011. Evolution Trends of Land Use/Land Cover in a Mediterranean Forest Landscape in Italy. In: Murgante B., Gervasi O., Iglesias A., Taniar D., Apduhan B.O. (eds) Computational Science and its Applications. International Conference in Santander, Spain, Proceedings, part I: 284-299.

Didier L., 2001. Invasion patterns of European larch and Swiss stone pine in subalpine pastures in the French Alps. Forest Ecology and Management 145(1-2): 67-77.

Geri F., Rocchini D., Chiarucci A., 2010. Landscape metrics and topographical determinants of large-scale forest dynamics in a Mediterranean landscape. Landscape and Urban Planning 95(1-2): 46-53. DOI 10.1016/j.landurbplan.2009.12.001.

Gielarek S., Klich D., Antosiewicz M., 2011. Zmiany powierzchni leśnej w Bieszczadach Zachodnich w XIX i XX wieku (Forest cover change in Western Bieszczady Mts. in $19^{\text {th }}$ and $20^{\text {th }}$ century). Sylwan 155(12): 835-842.

Giętkowski T., 2009. Zmiany lesistości Borów Tucholskich w latach 1938-2000 (Temporal change of forest area in Tuchola Pinewoods region between 1938 and 2000). Promotio Geographica Bydgostiensia IV: 149-162.

Hörsch B., 2003. Modelling the spatial distribution of montane and subalpine forests in the central Alps using digital elevation models. Ecological Modelling 168: 267-282. DOI http:/ / dx.doi.org/10.1016/S0304-3800(03)00141-8

Jankowska M., Lisiewicz S., 1998. Kartograficzne i geodezyjne metody badań zmian środowiska (The cartographic and geodetic methods of the environment changes analysis). Wyd. Akademii Rolniczej, Poznań: 50-51.

Józefaciuk A., Józefaciuk C., 1996. Mechanizm i wskazówki metodyczne badania procesów erozji (Mechanism and methodical instructions of erosion processes). Biblioteka Monitoringu Środowiska, Warszawa.

Kasprzyk S., 1961. Lasy górnicze w Królestwie Polskim (Mining forests in the Kingdom of Poland). Las Polski 12, 13/14.

Kłysik K., 1974. Warunki termiczne obszaru świętokrzyskiego (Thermal conditions of the Świętokrzyskie Region). Zeszyty Naukowe UE 63: 57-74

Kowalkowski A., 2000. Gleby (Soils). In: Cieśliński S., Kowalkowski A. (eds) Monografia Świętokrzyskiego Parku Narodowego. Wyd. ŚPN, Bodzentyn-Kraków: 169-196.

Kowalski B.J., 2000. Rzeźba (Relief). In: Cieśliński S., Kowalkowski A. (eds) Monografia Świętokrzyskiego Parku Narodowego. Wyd. ŚPN, Bodzentyn-Kraków: 107-128.

Kozak J., 2005. Zmiany powierzchni lasów w Karpatach Polskich na tle innych gór świata (Changes of forest cover in the Polish Carpathians in relation to other mountains of the world). Wyd. Uniwersytetu Jagiellońskiego, Kraków.

Kozak J., 2010. Forest Cover Changes and Their Drivers in the Polish Carpathian Mountains Since 1800. In: Nagendra H., Southworth J. (eds) Reforesting Landscapes Linking Pattern and Process. Landscape Series 10, Springer: 253-273. DOI 10.1007/978-1-4020-9656-3_11.

Kozak J., Estreguil C., Ostapowicz K., 2008. European forest cover mapping with high resolution satellite data: The Carpathians case study. International Journal of Applied Earth Observation and Geoinformation 10(1): 44-55. DOI 10.1016/j.jag.2007.04.003.

Kozak J., Estreguil C., Troll M., 2007a, Forest cover changes in the northern Carpathians in the 20th century: a slow transition. Journal of Land Use Science 2: 127-146. DOI 10.1080/17474230701218244.

Kozak J., Estreguil C., Vogt P., 2007b. Forest cover and pattern changes in the Carpathians over the last decades. European Journal of Forest Research 126: 77-90. DOI 10.1007/ s10342-006-0160-4.

Krysztofik E., 1976. Gospodarka leśna na obszarze Świętokrzyskiego Parku Narodowego w okresie od 1945 do 1970 r. (Forest management on the area of the Świętokrzyski National Park during the period since 1945 until 1970). Sylwan 120(4): 67-72.

Krysztofik E., Zieliński T., 1976. Zarys dziejów gospodarki leśnej od XIX wieku do II wojny światowej na terenie obecnego Świętokrzyskiego Parku Narodowego (Outline of the history of forest management from the XIX ${ }^{\text {th }}$ century until the World War II on the area of the present Świętokrzyski National Park). Sylwan 120(4): 57-65.

Kunz M., 2012. Zmiany lesistości Pomorza Zachodniego w ostatnich 400 latach (Changes in woodiness of West Pomerania during the last 400 years). Roczniki Geomatyki 4(54): 145-155.

MacDonald D., Crabtree J.R., Wiesinger G., Dax T., Stamou N., Fleury P., Lazpita J.G., Gibon A., 2000. Agricultural abandonment in mountain areas of Europe: environmental consequences and policy response. Journal of Environmental Management 59(1): 47-69.

Macias A., Szymczak M., 2012. Zmiany powierzchni leśnych na terenie miasta i gminy Krotoszyn w latach 1793-2005 (Changes in the forest cover in the town and commune of Krotoszyn in the years 1793-2005). Sylwan 156(9): 710-720.

Malczyk J., Świeżak J., 2008. Krajowy program zwiększania lesistości w systemie lokalnego planowania przestrzennego w Polsce (Influence of National Program of forested areas increase on the spatial planning system in Poland). 
Studia i Materiaty Centrum Edukacji Przyrodniczo-Leśnej 3(19): 291-301.

Markuszewska I., 2005, Zmiany powierzchni leśnej Wysoczyzny Kaliskiej w kontekście analizy struktury krajobrazu (The changes of the forest surface in the kalisz Plateau in terms of the of the landscape structure analysis). Badania Fizjograficzne nad Polska Zachodnia, seria A, Geografia Fizyczna 56: 93-106.

Musierowicz A., 1961. Mapa Gleb Polski w skali 1:300 000 (Polish Soil Map in the scale 1:300 000). IUNG Puławy.

Olszewski J.L., Szałach G., Żarnowiecki G., 2000. Klimat (Climate). In: Cieśliński S., Kowalkowski A. (eds) Monografia Świętokrzyskiego Parku Narodowego. Wyd. ŚPN, Bodzentyn-Kraków: 129-145.

Piussi P., 2000. Expansion of European mountain forests. In: M.F. Price and N. Butt (Editors), Forests in sustainable mountain development: a state of knowledge report for 2000. IUFRO Research Series 5, CABI Publishing, Wallingford-New York: 19-25.

Plan ochrony ekosystemów leśnych (Protection plan of the forest ecosystems), 2000. In: Plan ochrony Świętokrzyskiego Parku Narodowego. Archiwum ŚPN, Bodzentyn.

Polna M., 2005. Zmiany lesistości Polski w latach 1990-2001 (Changes in the woodiness of Poland in the years 19902001). Acta Scientiarum Polonorum. Silvarum Colendarum Ratio et Industria Lignaria 4(1): 51-60.

Połujański A., 1854. Opisanie lasów Królestwa Polskiego i guberni zachodnich Cesarstwa Rosyjskiego pod względem historycznym, statystycznym i gospodarczym (The description of forests belonging to the Kingdom of Poland and western governorates of the Russian Empire in respect of historical, statistical and economic factors). Warszawa, 1 : 227-294.

Puddu G., Falcucci A., Maiorano L., 2012. Forest changes over a century in Sardinia: implications for conservation in a Mediterranean hotspot. Agroforestry Systems. 85: 319330. DOI 10.1007/s10457-011-9443-y.

Reniger A., 1956. Zagadnienie wpływu zalesień i zadrzewień na erozję wodną na terenie województwa kieleckiego (The issue of afforestation and woodlots impact on water erosion in the Kielce Voivodeship). Sylwan 50(4): 33-55.

Romanowska M., 1934. Zmiany w zalesieniu Królestwa Polskiego w ostatnim stuleciu (The forest cover changes in the Kingdom of Poland in the last century). Czasopismo Geograficzne 12(3/4): 246-284.

Rudel T.K., Coomes O.T., Moran E., Achard, F., Angelsen A., Xu J., Lambin E., 2005. Forest transitions: towards a global understanding of land use change. Global Environmental Change 15: 23-31.

Shuttle Radar Topography Mission (SRTM), 2004. NASA Jet Propulsion Laboratory.

Siuta J., Żukowski B., 2011. Wzrost lesistości kraju od 1946 roku (Increase in the country forestation rate since 1946). Ochrona Środowiska i Zasobów Naturalnych 47: 133-145.

Skalos J., Engstova B., Trpakova I, Santruckova M. Podrazsky V., 2012. Long-term changes in forest cover 1780-2007 in central Bohemia, Czech Republic. European Journal of Forest Research 131:871-884. DOI 10.1007/s10342-011-0560-y.

Słomczyński J., 1934. Polskie mapy wojskowe. Wiadomości Stużby Geograficznej, 8(3): 363-386.
Stevens H., Tree R. 1951. Comparative cartography exemplified in an analytical and bibliographical description of nearly one hundred maps and charts of the American continent published in Great Britain during the years 1600 to 1850 . Henry Stevens, Son \& Stiles, London-New York.

Szafarkiewicz S., 1885. Wykaz lasów i sadów w Królestwie Polskim podług urzędowych danych z 1880 roku zebranych przez $B$. Aleksandrowicza $w$ porównaniu ze stanem lasów z 1856 roku (The list of the forests and orchards in the Kingdom of Poland based on the official data from 1880 collected by B. Aleksandrowicz in comparison to the forests state from 1856). Inżynieria $i$ budownictwo, 3 (dodatek nadzwyczajny).

Szymański B. 1993. Badanie zmian powierzchni leśnej Kielecczyzny w XIX i XX wieku na podstawie materiałów kartograficznych (The forest cover changes analysis in the Kielce Region in $19^{\text {th }}$ and $20^{\text {th }}$ century based on cartographic materials). Sylwan 137(4): 73-82.

Szymański B., 1978. Wstępne wyniki badań nad zmianami lesistości kielecczyzny (The initial results of investigations concerning the degree of afforestation in Kielce region). Przeglad Geograficzny 50(4): 603-619.

Szymański B., 1979. O źródłach i opracowaniach dotyczących zmian lesistości ziem polskich (About sources and papers on changes in forest cover on Polish lands). Sylwan 123(2): 57-69.

Szymański B., 1983. Zmiany powierzchni leśnej kielecczyzny w XIX i XX wieku (The Kielce Region forest cover changes in $19^{\text {th }}$ and $20^{\text {th }}$ century). Prace IBL Warszawa, 629.

Szymura T. H., Dunajski A., Ruczakowska A. M., 2010. Zmiany powierzchni lasów na obszarze Karkonoskiego Parku Narodowego w okresie 1747-1977 (Changes of forest cover in the Karkonosze National Park area in 1747-1977 period). Opera Corcontica 47(1): 159-166.

Terefenko P., Furmańczyk K., 2005. Wykorzystanie GIS w badaniach zmian krajobrazu (GIS analysis in evaluating landscape changes). Roczniki Geomatyki 3(4): 189-197.

Więcko E., 1948. Zmiany lesistości i zagospodarowanie lasów na ziemiach polskich $\mathrm{w}$ świetle rozwoju polityki leśnej (Changes of forest cover and the development of forests in Polish lands under the forest policy). Sylwan 92(2-4): 126-166.

Więcko E., 1986. Zmiany lesistości i rozmieszczenie lasów w okolicach Warszawy w świetle kartografii i innych źródeł (The forest cover and its distribution changes in the Warsaw surroundings in the light of cartography and other sources). Sylwan 130(2/3): 127-136.

Wilson J.W., 2005. Historical and computational analysis of long-term environmental change: forests in the Shenandoah Valley of Virginia. Historical Geography 33: 33-53.

Wulf M., Sommer M., Schmidt R., 2010. Forest cover changes in the Prignitz region (NE Germany) between 1790 and 1960 in relation to soils and other driving forces. Landscape Ecology 25: 299-313. DOI 10.1007/s10980-009-9411-3.

Zaręba R., 1958. Lasy kielecczyzny w świetle dokumentów archiwalnych (The Kielce region forests in the light of archival documents). Las Polski 19: 5-9. 